\title{
Promoting Ancestry as Ecodomy in Indigenous African Religions
}

\author{
CORNELIU C. SimuT, PhD Aberdeen \\ University of Pretoria \\ Hatfield | Lynwood | South Africa \\ Phone: +40 727885646 \\ Email: corneliu.simut@gmail.com
}

\begin{abstract}
This paper is an attempt to offer a concrete contribution to the study of indigenous African religions and in particular to the support of creating a set of traditions from whose perspective one could engage in the study of indigenous African religions as well as of African spirituality in general. Bearing in mind that one of the most prominent features of these studies is the constant effort to decolonize the field in order to move beyond former imperialistic interpretations into specifically africanized postcolonial hermeneutics based on the recognition of distinctive African identities, I suggest a methodology which focuses not so much on the decolonization or post-colonization of the study of indigenous African religions, but rather on a unifying theme which has an evident constructive potential. Combining two notions, ancestry and ecodomy, this methodology seeks to support the development of current efforts to build African traditions in the study of indigenous African religions by pointing not only to an aspect which is common to most African religions, namely ancestry and the role of ancestors, but also to the need for a more positive tendency which is able to instill a constructive trend [as different from if not opposite to de- or post-colonization hermeneutics] in the study of indigenous African religions by using the notion of ecodomy. Defined in terms of a constructive process, ecodomy seeks to provide families and communities with a common element, that of ancestors, which is not only specific to African spirituality but also potentially capable of strengthening and improving the life of African people. Thus, this methodology based on working with ancestry as economy is applied to four distinct scholars and their specific approaches to indigenous African religions: John S. Mbiti, who believes that ancestors have mainly social, not religious roles; Issiaka P. Lalèyê, for whom ancestors make a connection between the social and religious aspects of life; Jacob K. Olupona, who restricts ancestors to religion, and Israel Kamudzandu, in whose philosophy ancestors can provide African societies with the possibility of moving beyond their indigenous religions into accepting other religious beliefs, such as those provided by Christianity.
\end{abstract}


Key words: ancestors, ecodomy, religion, African, family

\section{Introduction}

A very hot potato in the academic study of indigenous African religions these days appears to be the issue of methodology. While the heat of the said potato disseminates over culture, philosophy, and society, the interest of this paper remains circumscribed to the problematic of religion. Thus, in recent years, questions about the validity of studying indigenous African religions as a field on its own right began to surface especially with regard to the actual way in which these studies should be carried out. While it goes almost without question that indigenous African religions must move beyond the Colonial era, the issue of how to walk in that direction has not yet found a very firm response regardless of whether one has only African religions in mind or one, as Edward P. Antonio points out, also includes Christianity in the discussion (Antonio 2006: 38-39).

\section{The Need for Decolonization}

Since colonial perspectives on indigenous African religions are presently seen by a significant number of African philosophers and religious scholars as imperialistic or, in the words of Kwasi Wiredu (2006: 291), as “an imposition”, and thus, quite rightly, faulty in their methodologies, moving beyond a colonial understanding of indigenous African religions seems to be bit more complex a process than it appears at first glance. Colonization imposed not only political but also cultural norms; this is why, Wiredu contends (2006: 291), the process of decolonization must attempt to create a way of thinking, a concrete philosophy which attempts to establish "definite modes of conceptualization" in full accordance with indigenous African ways of thinking devoid of Western concepts, patterns, and even languages (2006: 294). To take just one example: indigenous African spiritualities must find a way to renounce traditional Western dichotomies such as "the spiritual versus the physical, the supernatural versus the natural, the mystical versus the nonmystical, the religious versus the secular, being versus nothingness" (Wiredu 2006: 294). In other words, Wiredu proposes that indigenous African thought must "go to the roots" in order to identify the compatibilies and incompatibilites between Western philosophy and African spirituality or, in religious terms, between Christianity as a religion and indigenous African religions (Wiredu 2006: 296).

At the same time, the decolonization of African spirituality presupposes leaving behind Western philosophical ways of thinking or, in the words of Messay Kebede (2004: xii), "the emancipation of 
the African mind from the debilitating ascendancy of Western episteme". It is within the same lines that Sabelo J. Ndlovu-Gatsheni (2013: 52) explains the need for decolonization which is seen as an attempt to obtain "epistemological freedom" from European and American philosophies. This effort to decolonize African spirituality should focus not only on "secular philosophy" but also on the "geo-political location of theology... and scientific reason". All aspects of the mind should be subject to decolonization to the point that the African spirit finds a way to return to itself, to its genuine interiority which is set free from any non-African influences. This is why the decolonization of African spirituality is also a liberation of consciousness, as Munyaradzi Mawere shows (2011: 27), which goes hand in hand with empowering the same African consciousness to the point of being capable of producing its own culture.

Thus, regardless of whether one wants to decolonize the study of indigenous African religions in particular or, to use Kebede's favorite phrase, the "the African mind" in general (Kebede 2004: 111 ), or one just intends to step beyond any colonial interpretations thereof, the so-called postcolonial stage which is supposed to offer a specifically Africanized understanding of African culture, philosophy, and religion is still something to be desired rather than something that can be said to have turned into a "tradition" or preferably more such "traditions" despite the fact that African spirituality, and especially religion, can hardly be conceived in monolithic terms (Ikuenobe 2006: 23-24).

\section{In Search of Methodological Traditions}

This is why scholars like Ezra Chitando, Afe Adogame, and Bolaji Bateye recently started to delve into the issue of whether or not one can speak about African traditions in the study of indigenous African religions. Touching on various key aspects of today's study of African religions like "intellectual decolonization", "the absence of African voices", the assumption of a "distinctive [African] identity", and the need of the "colonial subjects" to develop a language in order to "speak back" and, in so doing, to leave behind a specifically European approach, Chitando, Adogame, and Bateye are trying to articulate as well as explain the need for the development of African traditions in the field of African religions (Chitando at all 2012: 3-7). While the hurdles on this road are not only numerous but also difficult to surpass mostly because they include objective situations like the usual violence associated with decolonization (Abdullah 2015: 47), impoverished institutional conditions of universities in most Sub-Saharan universities as well as the subjective desire of some scholars to be develop internationally rather than remain forever confined to their Africannessalthough this can be very difficult to give up in reality, as Aloysius M. Lugira claims (Lugira 2009: 
106) - Chitando, Adogame, and Bateye speak with a single voice about the need to start building specific African traditions in the study of indigenous African religions (Chitando et all 2012: 9).

Although this paper cannot provide a specifically African perspective on the study of indigenous African religions given the author's European origins, it can still contribute to the development of this trend which seeks to build an array of African traditions when it comes to the study of African spirituality in general, and African religion in particular. Concretely, I suggest to build a methodology based on the idea of ancestry, which is specific to most indigenous African religions, as well as shaped by the notion of ecodomy defined as "the art of inhabiting instead of dominating the earth, our house" by Geiko Müller-Fahrenholz, who also extends its meaning to "any constructive process" (Müller-Fahrenholtz 1995: 109). In other words, while the idea of ancestry speaks of a common denominator for the majority, if not all indigenous African religions, the concept of ecodomy provides us with a constructive way of looking at these religions.

This methodology is supposed to be capable of standing on its own irrespective of whether or not contemporary or future scholars succeed in detaching themselves from colonial interpretations and move into a post-colonial, more or less Africanized and decolonized perspective on indigenous African religions to create one or more valid specifically African intellectual traditions. To begin with, however, I identified four distinct perspectives on how ancestry works as ecodomy, or constructively, in the study of indigenous African religions.

Thus, while all four approaches see ancestors in ecodomic terms as factors which contribute in a positive way to the development of families and communities, each of them deals with religion in a specifically distinct way: first, John S. Mbiti's theory proposes that ancestors have little or no religious significance, but only social relevance; second, Issiaka P. Lalèyê suggests that ancestors mediate the transition from the social to the religious aspects of daily life; third, in Jakob K.

Olupona ancestors should be approached exclusively in religious terms; and fourth, Israel Kamudzandu believes that ancestors can assist in moving beyond indigenous African religions into positive relationships with other religions, specifically with Christianity.

\section{John S. Mbiti: Ancestry as Ecodomy without Indigenous African Religions}

One of the first aspects that people belonging to Western intellectual traditions need to understand regarding the idea of ancestors in African religions is not only who are these ancestors and what is the relationship between them and the living. As John S. Mbiti poignantly shows writing from an 
Anglican Protestant perspective with English cultural influences-harshly criticized by Taban lo Liyong, a native of Uganda, with a certain lack of courtesy (Liyong 1988: 81-91) - the Western traditional image of African religions being based on sacrifices to ancestors or worship to ancestors is deficient. While it is crucial to see that ancestors play a vital role in African religious spirituality, Mbiti — who comes from the British-dominated East African Kenya-insists that a more accurate way to understand the African perspective on ancestors is the necessity to keep in touch with ancestors, a point made also by Leonard E. Barrett (1974: 25). In other words, for African people, bringing sacrifices to or worshipping ancestors is only a part of their religious spirituality; it is much more important to understand that, for African spirituality, the need of the living to stay in touch with their departed relatives plays a far greater role in their non-religious frame of mind and practically in various social contexts (Mbiti 1999: 8-9).

In trying to stay in touch with their ancestors, Africans fulfill one of their most basic social needs, that of remaining in communion with those who were physically part and now, through death, are spiritually part of their families by existing, as Donatus O. Chukwu writes, "in another realm of life" (Chukwu 2011: 183). In other words, in seeking communion with their ancestors, Africans are constantly building and rebuilding their homes, they are reinforcing their family connections which provide them with a sense of social comfort and safety. Thus, Mbiti proposes a social ecodomy of ancestry which does not need religious aspects to achieve its fundamental goal to continuously build family connections, as reinforced by Edwin A. Udoye, before as well as beyond the reality of death (Udoye 2011: 102).

Regarding death, another aspect which is of paramount importance for the idea of ancestors in African spirituality is to understand that, while in Western societies, ancestors generally refer to the departed (Hopfe and Woodward 2009: 56) regardless of whether one believes in their continuous existence as spirits or souls after death, in African religions, the departed go through two distinct stages in their existence following the moment of death. First, until the four of five generations, the departed are still remembered by what Mbiti calls the "immediate members" of their families, in which case the ancestors are considered "living dead", or the dead who live in the consciousness of the living as both human and spirits, a common feature of African thought in its entirety, as shown by Adisa O. Joke, Adebiyi A. Tamurat, and Adu. O. Temitope (2014: 330). Second, when all the immediate members of the family of the deceased have died and there is nobody left alive to remember the dead, then the departed go beyond the phase of being "living dead" into that of being full spirits (Mbiti 1999: 83). 
Remembering the dead, however — and Mbiti is very emphatic in underlining this aspect — is not what Westerners call "ancestor worship", nor are they deeds associated with religion. Keeping the memory of a departed relative alive is rather a feature of social, nor religious behavior for African spirituality, so for as long as a dead person is kept alive through various acts of remembers that person continues to exist in the Sasa and is thus a living dead. When his Sasa is over and he is no longer remembered, he slips into the Zamani of impersonal immortality when he can rightfully be included in the long line of ancestors (Mbiti 1999: 25). Thus, for the Anglican Protestant Mbiti, the idea of ancestry and the role of ancestors in African thought are mainly non-religious or only partially religious, while their predominant focus has to do with the social and family realm. Specifically, the connection with ancestors consolidates family ties even beyond death, so it cements social relationships in an ecodomy that functions without religious connotations.

\section{Issiaka P. Lalèyê: Ancestry as Ecodomy towards Indigenous African Religions}

Writing from a Roman Catholic perspective with a French cultural background, Issiaka P. Lalèyê proposes a rather different approach to the idea of ancestry in African spirituality. Unlike the East African Mbiti, who was born in the English cultural influences of a predominantly Anglican Protestant Kenya, the West African Lalèyê-born in the French cultural context of the mainly French Roman Catholic Benin — suggests that the idea of ancestry as well as the role of ancestors are profoundly connected with the reality of religious thought. First, however, according to Lalèyê, it has to be established that while ancestors refer to the departed, not all the persons who died can be included in the category of ancestors, so not all the dead are in fact ancestors, a fact which - as Robert Baum notices - is usually decided by the Supreme Being (Baum 2005: 83-84). This is why Lalèyê insists that burial rituals must be kept separate both from the cult of ancestors and from what he calls "the process of ancestralization" or the specific rituals whereby a dead person is turned into an ancestor (Lalèyê 1996: 657).

Since ancestralization, however, is a process and it is connected with a cult, it becomes evident that in Lalèyê, the role of ancestors cannot be restricted to the social realm; it actually moves beyond it into the sphere of religious thinking and practices which are all aimed at bestowing blessings upon the living, an idea confirmed by Maria Frahm-Arp (2010: 117). In other words, in Lalèyê's paradigm, ancestors are meant to strengthen the lives of the living by offering them blessings which points to an ecodomical approach to ancestry that bridges the social and the religious aspects of indigenous African people mostly because, as Theo Sundermeier writes, for the African mind there 
is not real distinction between the social and religious aspects of life which is more a Western dichotomy than an African conviction (Sundermeier 1998: 122).

Since the idea of ancestry is so closely connected with the reality of death, it is crucially important for Lalèyê to offer a definition of death in African spirituality. Thus, for the African mind in general, death cannot be considered the end of life; on the contrary and despite the paradoxical nature of such existential convictions, in African cultures, death is a continuation of life, as explained by David T. Ngong (2013: 113). Although the general impression about death is that it damages the reality of life to the point of extinction, for the African mind, death does exactly the contrary: while it dramatically alters life, it actually strengthens it and it pushes it into some sort of further continuance. For a person who is considered dead in a traditional Western society, life continues in a different way as far as African spirituality is concerned. The dead person is not actually dead; he or she continues to live in an altered, dramatically modified state of life; this is why, for Lalèyê, death does nothing but take life to a different level (Lalèyê 1996: 657-658).

When death occurs, however, the idea of ancestry takes shape because the deceased are worshipped as saints, a juxtaposition also defended by Daniel J. Paracka Jr (2003: 89), they provide the living members of their families with peace and happiness and, in turn, the living members of their families make sure that ancestors are remembered. Moreover, elderly people approaching death are somehow proleptically considered saints and ancestors if they have many descendants who can remember them after death and thus help them avoid oblivion, as also shown by Igboin O. Benson (2011: 165-166). When this is not the case, old people facing death suffer terribly from what can be considered a spiritual and religious grief which, as Lalèyê points out, "is much more severe than the suffering caused by material deprivation and physical abandonment" (Lalèyê 1996: 660). Consequently, for Lalèyê - a West African originating in a Roman-Catholic context - the idea of ancestry has obvious religions connotations which, coupled with the social and communitarian aspects of the family (Lalèyê 1996: 661), offer a broader spectrum of features for the role of ancestors in African spirituality with the ecodomic purpose of helping the living by teaching them valuable lessons for life.

\section{Jacob K. Olupona: Ancestry as Ecodomy in Indigenous African Religions}

For Jacob K. Olupona, who comes from Nigeria, also a West African country where Protestant Christianity has established a significant presence, and focuses on some African religions which pertain to Central Africa, ancestors belong to a rather different pattern of thought. Thus, if for Mbiti 
ancestors have almost nothing to do with religion as they serve a social function and for Lalèyê they do belong to religion since they can become saints, in Olupona ancestors are presented from the very start as a component of religion mostly because they are introduced as belonging to the realm of Gods and spirit beings; furthermore, as Maulana Karenga explains, for the African mind, everything is religious and has "religious relevance" (Karenga 2000: 273). This is why Olupona makes it clear that in indigenous African religions - and here he refers to those professed in Nigeria and Uganda - ancestors are included in a wider range of spiritual beings alongside "deities, spirits, gods, ..., and personal and impersonal forces" (Olupona 2014: 20).

It is important to notice that for these African religions, all these beings which include the ancestors, are seen as having an active connection with the world of the living to the point that they become what Olupona calls "active agents in the created world" (Olupona 2014: 20). For Olupona, therefore, there is little doubt, if any, that ancestors belong to the realm of religion since they can influence daily human life, as also shown by Monica A. Coleman (2011: 224), and belong to the "African pantheon of gods, goddesses, spirits, and other nonhuman beings" (Olupona 2014: 20). This pantheon contains a huge variety of divine beings, or beings with divine status, so as part of this impressive number of gods, ancestors are venerated on a regular basis. It is important though to understand that this veneration should be seen in terms of family relationship; not all ancestors are venerated by all people. Families tend to focus on certain ancestors, especially those whom they know personally, so what happens is that various persons and families restrict their pantheon to only a certain, rather small, number of deities and ancestors for the specific purpose, as Julius Bailey notices, of providing the family with positive benefits, such as harmony (Bailey 2008: 104).

It is also vital to understand, as Olupona explains, that this connection with ancestors which should be seen in terms of a family relationship has a very important dimension, namely reciprocity, which is believed to be a divine feature or, as Jawanza E. Clark reveals, "is part of the substance of God" (Clark 2013: 665). The interaction of the living with ancestors - who are the spirits of the departed - is a mutual relationship which defines the daily affairs of a family. The connection with ancestors is important in African religions because it represents a real liaison with the parents who died. Given that ancestors are the spirits of departed members of the family, and specifically with "deceased parents", their veneration is held in high regard (Olupona 2014: 20).

Similarly, the case of twins is particularly prominent in African spirituality because, in most cases, they are believed to be ancestors by birth since, as Patrick Bellegarde-Smith explains, twins represent both life and death (Bellegarde-Smith 2005: 6). The religious function of ancestry in this 
case becomes relevant when one of the twins dies and leaves the other one in the natural world. Since the deceased twin is an ancestor and given his connection with this twin brother, the two babies - it is believed - would want to stay together in the afterlife because, in some African religions, they are considered "souls who die in childhood but keep returning by being born again and again to the same parents" (Allan et all 2012: 42). This is why, if one of them dies, in order for the surviving twin to remain in the world of the living, elaborate religious ceremonies are performed - including the commission by the parents of "twin statuette" representing the departed child — so that "the deceased twin is kept happy" in the other world and in a state of mind which allows the surviving twin, but also the next generation of children as shown by Benjamin C. Ray (1976: 133), to enjoy life in the realm of the living (Olupona 2014: 32-33). Thus, for Olupona, belief is ancestors is neither primarily social as in Mbiti, nor an issue of gradual transition from a social to a religious level, but a fully fledged religious reality which has immediate ecodomical effects - positive and negative - in the world of the living.

\section{Israel Kamudzandu: Ancestry as Ecodomy beyond Indigenous African Religions}

One of the most challenging perspectives on indigenous African religions, but also one which can attract an immense load of criticism, is that proposed by Israel Kamudzandu, a native of Zimbabwe and a United Methodist Protestant pastor in the United States of America. Born and raised in Zimbabwe but educated both in his native country and in the United States, Kamudzandu sees African religions in a very close and interdependent relationship with Christianity. Moreover, it is the concept of ancestry which makes possible the connection between indigenous African religions and the Christian religion with the intended result of exalting "the non-Christian [African] religions, including traditional African ones to the level of Christianity", a thesis proposed by Jesse N. K. Mugambi (1992: 59). To illustrate this thesis, Kamudzandu resorts to the beliefs of the Shona people from Zimbabwe's South African context, which he explains in terms of a liaison with Christian doctrines. Thus, he explains that in Shona cosmology the idea of ancestry plays a crucial role because ancestors are seen primarily as mediators, an idea which is explored also by David Chidester (1992: 6). First, they mediated between the living and God, or gods, and second they mediate between indigenous African religions and Christianity (Kamudzandu 2010: 35).

This is by far the most ecodomic approach regarding the role of ancestors in indigenous African religions. While all attempt to use the idea of ancestry as something essentially positive, as a reality which can be seen as ecodomy, as building, strengthening, and consolidating social and family relationships, this perspective is consistently different. Thus, if in Mbiti the ecodomy of ancestors is 
primarily social, in Lalèyê both social and religious, and in Olupona essentially religious, in Kamudzandu things move beyond religion towards another religion. Kamudzandu provides a model of ancestry as ecodomy not only for the sake of African people and their Africanness as common feature of all indigenous African religions (Ludwig and Adogame 2004: 10) —although this seems to be his primary goal—but also with possibly concrete results in the religious experience of people sharing other religious views, especially those promoted by Christianity.

In the mentality of this specific South African people, prayers to divinities are always performed through ancestors, so ancestors make the actual connection between humanity and God, as also pointed out by Renee K. Harrison (2009: 46). From this perspective, ancestors are seen as positive influences, mostly because - as a result of their mediating function - they are capable of providing the society of the living with "harmony", a feature — in the words of Veli-Matti Kärkkäinen"routinely assigned to the African context" (Kärkkäinen 2007: 350). Conversely, if ancestors are ignored or in any way pushed aside from this specifically religious function of theirs, the community of the living runs the risk of loosing its stability and balance because ancestors, departed as they are-Andrew West explains - are considered members of the community (West 2014: 49). This is why, in the philosophy of the Shona people, ancestors serve a deeply religious role which is kept alive by means of rituals aimed at remembering the ancestors in key aspects of man's life such as marriage or various agricultural works (Kamudzandu 2010: 13).

Thus, ancestors provide communities with peace and blessings, which appears to be their main function, a perpective which seems to be supported also by Lewis M. Hopfe and Mark R. Woodward (2009: 57). Even when ancestors are neglected and communities are faced with difficulties, it is not the ancestors themselves who should be blamed for this situation, but rather the community which was careless enough as to neglect them. In Kamudzandu's understanding, ancestors are builders, not destroyers, they grant blessings, not destruction (Kamudzandu 2010: 176). They constructively bridge cultures and religions, and when cultures and religions are not in good terms with each other, the blame rests not with ancestors, but with the living who must have ignored what George Brandon calls the "intimate connection" between ancestors and their descendants (Brandon 2012: 169). This is why, ancestors must never be confused with the Supreme Being (Idamarhare 2010: 53) or with God-Kamudzandu, by the way, does not say which God, that of African religions or that of Christianity. Regardless of this imprecision, it is crucial to see that, in Kamudzandu, ancestors do not and cannot cause destruction, as God or a god could do. Quite the contrary - and in this Kamudzandu runs against the general trend about how ancestors are perceived in indigenous African religions as "causative agents of both good and evil" (Anderson 2010: 48) - 
he shows that ancestors are there to secure blessings, peace, and prosperity to all those who still roam through the world of the living especially by building a bridge between indigenous African religions and Christianity (Kamudzandu 2010: 180). Kamudzandu's model of ancestry as ecodomy is attempting to build something positive not only for people belonging to specifically African contexts, but also to those who live and believe in a totally different way, especially in accordance with the religious teachings of Christianity.

\section{Concluding Remarks}

Within the current academic context of the study of indigenous African spirituality and religions, which is decisively set on the path of de- and post-colonization for the sake of establishing newand hopefully specifically African - traditions in the study of African religions, the need to find a methodology that is efficient in helping this trend take shape appears to be more than merely important. While, objectively speaking, there is no such thing as a perfect methodology, more or less effective methodologies in supporting certain academic tendencies may or may not prove to be helpful on the long run. This paper is an attempt to build a methodology which may offer a certain degree of effectiveness in promoting the general efforts to establish new traditions in the contemporary study of African religions by focusing on two key elements: first, a common denominator for most indigenous African religions, which was found in the idea of ancestry and the corresponding role of ancestors in African spirituality, and second, a concept that is able to push this concept in the right direction, namely use it in a constructive way by means of the notion of ecodomy.

Broadly defined as "constructive process", ecodomy can steer the idea of ancestry as well as emphasize the positive character of ancestors in a way which improves the life of families and communities, even to the point of flourishing. Four distinct approaches were scrutinized in order to see how ancestry can work as ecodomy in the contemporary study of indigenous African religions: first, the view which believes that ancestors have only social, not religious functions, promoted by John S. Mbiti; second, the theory that ancestors support the transition from the social to the religious aspects of life, found in Issiaka P. Lalèyê; third, the perspective that confines ancestors exclusively to religious roles, developed by Jacob K. Olupona; and fourth, the proposal that ancestors should move beyond indigenous African religions towards other religions, most notably Christianity, as one can read in Israel Kamudzandu. 
Regardless of the distinctive elements which differentiate among these four approaches, Mbiti, Lalèyê, Olupona, and Kamudzandu use the notion of ancestry in a constructive, ecodomical way. Thus, ancestors are seen as being devotionally more important than deities which can be helpful if/when African societies become significantly affected by secularization. Then, ancestors are said to be always closer and even dependent on their immediate families which is beyond doubt an advantage for the wellbeing of families in any specific human context. Ancestors are also believed to be present in the most important moments of one's life, such as birth, marriage, and death, which can only improve the quality of one's life in such phases of life. Ancestors can be approached and consulted, especially by the elderly, which—despite the increasing secularization of some segments of African life - can function as a soothing reality for those approaching the end of life. Likewise, ancestors are believed to be capable of bestowing blessings or punishments, an aspect which can offer some ethical balance in some of the most critical moments of one's life, when split-second moral decisions that can affect somebody else's life must be taken. Since ancestors belong to the real of the departed, a certain awareness of their their continuous existence beyond the final limit of natural life can raise one's awareness not only about the imminence of death but also about the value of life. In being part of the life of the living, ancestors - as deceased parents - can elevate one's apprehension of his or her humanity, not only in relationship to himself or herself but also in close connection with his or her children. In being revered, honored, and respected, ancestor can teach those who are still alive that the fundamental human values are worth clinging to not only in life but also in death.

All these characteristics of ancestors, so poignantly present in the thought of Mbiti, Lalèyê, Olupona, and Kamudzandu, can be used in an ecodomical fashion both to make the life of communities better in more than just one way and to support the development of new-preferably African - traditions in the study of indigenous African spirituality for the sake of bequeathing an ever improved quality of life to next generations throughout the African continent.

\section{Bibliography}

Allan T, Flemming F and Phillips C (2012) African Myths and Beliefs. New York, NY: Rosen Publishing.

Antonio EP (2006) The Hermeneutics of Inculturation. In Antonio EP (ed) Inculturation and Postcolonial Discourse in African Theology. New York, NY: Peter Lang.

Bailey J (2008) Angola. In Juang RM and Morrissette N (eds) Africa and the Americas. Culture, Politics, and History, volume 1. Santa Barbara, CA: ABC-CLIO, pp. 104-106. 
Baum R (2005) African Religions: an Interpretation. In Appiah DA and Gates Jr. HL (eds) Africana.

The Encyclopedia of the African and African American Experience, volume 5, second edition.

Oxford: Oxford University Press, pp. 82-86.

Bellegarde-Smith P (2005) Introduction. In Bellegarde-Smith P (ed) Fragments of Bone. Neo-

African Religions in a New World. Chicago, IL: University of Illinois Press, pp. 1-12.

Benson IO (2011) Human Rights in the Perspective of Traditional Africa: A Cosmotheandric Approach. Sophia 50(1): 159-173.

Brandon G (2012) Lucumi Divination, the Mythic World, and the Management of Misfortune. Anthropologica 54(2): 167-198.

Chidester D (1992) Religions of South Africa. London: Routledge.

Chitando E, Adogame A and Bateye B (2012) Introduction. African Traditions int he Study of

Religion in Africa. In Adogame A, Chitano E and Bateye B (eds) African Traditions in the Study of Religion in Africa. Farnham: Ashgate, pp. 1-13.

Chukwu DO (2011) The Church as the Extended Family of God. Toward a New Direction for African Ecclesiology. Bloomington, IN: Xlibris.

Clark JE (2012) Indigenous Black Theology. Toward and African-Centered Theology of the AfricanAmerican Religious Experience. New York, NY: Palgrave Macmillan.

Clark JE (2013) The Great Ancestor: An African Conception of God. In Diller J and Kasher A (eds)

Models of God and Alternative Ultimate Realities. Dordrecht: Springer, pp. 661-668.

Frahm-Arp M (2010) Professional Women in South African Pentecostal Charismatic Churches.

Leiden: Brill.

Hopfe LM and Woodward MR (2009) Religions of the World, eleventh edition. New Jersey, NJ:

VangoBooks/Pearson Education.

Idamarhare AO (2010), The Unknown God: Paul's Address at Areopagus in African Context. In

Onibere SGA and Adogbo MP (eds) Selected Themes in the Study of Religions in Nigeria.

Lagos: Malthouse Press, pp. 45-58.

Ikuenobe P (2006) Philosophical Perspectives on Communalism and Morality in African Traditions. Lanham, MD: Lexington Books.

Joke AO, Tamurat AA and Temitope AO (2014) Instances of Yorùba Worldview in D. O. Fágúnwà's Novels. International Journal of Arts and Sciences 7(6): 325-350.

Kamudzandu I (2010) Abraham as a Spiritual Ancestor. A Postcolonial Zimbabwean Reading of Romans 4. Leiden: Brill, 2010.

Karenga M (2000) Black Religion. In Wilmore GS (ed) African American Religious Studies. An Interdisciplinary Anthology. Durham, NC: Duke University Press, pp. 271-300. 
Kärkkäinen VM (2007) The Trinity. Global Perspectives. Louisville, KY: Westminster John Knox Press.

Kebede M (2004) Africa's Quest for a Philosophy of Decolonization. Amsterdam: Rodopi, 2004. Lalèyê IP (1993) Les religions de l'Afrique noire. Dans Delumeau J (sous la direction de) Le fait religieux. Paris: Fayard, pp. 643-713.

Lalèyê IP (1996) Religiile Africii negre. In Delumeau J (ed) Religiile lumii. București: Humanitas, pp. 609-675.

Liyong Tl (1988) Reverend Doctor John S. Mbiti is a Thief of Gods. In Holst Petersen K (ed)

Criticism and Ideology. Second African Writer's Conference, Stockholm 1986. Stockholm:

Nordiska Afrikainstitutet, pp. 81-91.

Ludwig F and Adogame A (2004) Introduction. Historiography and European Perceptions of

African Religious History. In Ludwig F and Adogame A(eds) European Traditions in the

Study of Religion in Africa. Wiesbaden: Otto Harrassowitz, pp. 1-22.

Lugira AM (2009) African Traditional Religion, third edition. New York, NY: Chelsea House.

Mbiti JS (1996) The Study of African Religions and Philosophy. In Asante MK and Abarry AS (eds)

African Intellectual Heritage. A Book of Sources. Philadelphia, PA: Temple University Press, pp. 287-293.

Mbiti JS (1999) African Religions and Philosophy, second edition. Oxford: Heinemann Educational Publishers.

Mugambi JNK (1992) Critiques of Christianity in African Literature. Nairobi: East African

Educational Publishers.

Müller-Fahrenholtz G (1995) God's Spirit. Transforming a World in Crisis. London: Continuum.

Ngong DT (2013) Theology as Construction of Piety. An African Perspective. Eugene, OR:

Resource Publications/Wipf and Stock.

Olupona JK (2014) African Religions. A Very Short Introduction. Oxford: Oxford University Press.

Paracka Jr. DJ (2003) Athens of West Africa. O History of International Education at Fourah Bay

College, Freetown, Sierra Leone. New York, NY: Routledge.

Ray BC (1999) African Religions. Symbol, Ritual, and Community. New Jersey, NJ: Pearson.

Sundermeier T (1998) The Individual and Community in African Traditional Religions. Hamburg:

LIT Verlag.

Udoye EA (2011) Resolving the Prevailing Conflicts between Christianity and African (Igbo)

Traditional Religion through Inculturation. Berlin: LIT Verlag.

Wiredu K (2006) A Companion to African Philosophy. Oxford: Wiley-Blackwell.

Ndlovu-Gatsheni SJ (2013) Coloniality of Power in Postcolonial Africa. Myths of Decolonization.

Dakar: Council for the Development of Social Science Research in Africa. 
Mawere, M (2011) African Belief and Knowledge Systems. A Critical Perspective. Mankon: Langaa Research and Publishing.

\section{Note}

This article is part of a two-year postdoctoral research program (2015-2017) at the Faculty of Theology, the Department of Dogmatics and Christian Ethics, University of Pretoria, under the supervision of Professor Johan Buitendag.

\section{Biography}

CORNELIU C. SimUȚ is Postdoctoral Research Fellow at the Faculty of Theology within the University of Pretoria, working with Professor JOHAN BUITENDAG on ancestry as ecodomy in various social, cultural, and religious contexts. His latest work is F. C. Baur's Synthesis of Hegel and Böhme. Redefining Christian Theology as a Gnostic Philosophy of Religion. Leiden: Brill, 2015. 